ORIGINAL ARTICLE

\title{
Videos have a role in postgraduate necropsy education
}

\author{
J L Burton, G Diercks-O'Brien, G N Rutty
}

J Clin Pathol 2004;57:877-881. doi: 10.1136/icp.2003.010637

See end of article for authors' affiliations .....................

Correspondence to: Dr J L Burton, Academic Unit of Pathology, E-Floor, Medical School, Beech Hill Road, Sheffield, S10 2RX; j.l.burton@shef.ac.uk

Accepted for publication 14 January 2004

\begin{abstract}
Aims: This is the first study to investigate the usefulness of structured, scripted videos as an adjunct to the mortuary based training of histopathology trainees in necropsy techniques.

Methods: Four structured and scripted videos describing aspects of necropsy health and safety, evisceration, general dissection techniques, specialist dissection techniques, and reconstruction were shown to histopathology trainees attending the 2001 University of Sheffield short course on the autopsy. Delegates who agreed to participate in the study were asked to complete a short questionnaire seeking Likert-type and free text responses concerning the usefulness of the videos in postgraduate necropsy training. Free text responses were analysed using a themed content analysis.

Results: All 38 delegates who viewed the videos agreed to participate in the study. Of these, 35 found the videos enjoyable and 34 found them interesting. Thirty one felt the videos enhanced their learning experience. Advantages of the videos included the ability to learn about specialist techniques rarely encountered in the mortuary, the ability to teach large numbers of students at once, allowing students to learn at their own pace, and as a tool for revision. Repetition between the videos, a lack of interactivity, and a lack of sufficient detail on general necropsy techniques were felt by participants to be the principal disadvantages of this teaching tool.

Conclusions: Videos are an acceptable teaching tool for students. They have a valuable role to play as an adjunct to dissection in teaching junior histopathology trainees about specialist necropsy dissection techniques.
\end{abstract}

$\mathrm{T}$ he past 40 years have seen the publication of more than 26000 articles on the necropsy. These deal with the usefulness and decline of the consent necropsy and the role of the necropsy in undergraduate medical education. ${ }^{1-7}$ Therefore, it is surprising that, given intense public and professional interest in the necropsy, ${ }^{8}$ and the efforts expended on elucidating its roles in undergraduate education, the literature on the education of histopathology trainees in necropsy practice is virtually non-existent.

Histopathology trainees have traditionally been taught necropsy techniques by an apprenticeship process with varying degrees of supervision. We aimed to see whether videos of necropsy techniques could be used to supplement and augment training in necropsy practice.

\section{METHODS \\ Videos}

In 2000, the University of Sheffield (UK) learning media unit produced a series of four structured, scripted necropsy training videos for medical education with the consent of the relatives of the deceased (table 1). ${ }^{9}$ These were aimed at undergraduates and postgraduate histopathology trainees. The programmes were developed to be viewed individually or as a series. To our knowledge, this is the only video series of its kind in the world.

The video series was shown to delegates (senior house officers (SHOs) and specialist registrars (SpRs) in histopathology from around the UK) on the "2001 University of Sheffield short course on the autopsy" following a "live" necropsy demonstration. Because this research was intended to survey a new proposition, it was explorative in nature and used both quantitative and qualitative research methods. Consequently, the sample was not intended to be either comprehensive or representative.

Delegates who agreed to participate in our study completed a short questionnaire seeking categorical responses (strongly agree, agree, disagree, strongly disagree) to six "Likert-type" questions, and free text responses to questions about the usefulness of the videos as a teaching medium (table 2). The answers to the Likert-type questions were collated and analysed in the statistics package SPSS Version 9.0. Given the sample size, only quantitative descriptive statistics were undertaken. Free text responses were subjected to a themed content analysis in which themes were derived by aggregating similar statements from within the responses. ${ }^{10} 11$

\section{RESULTS}

All 38 delegates who viewed the videotape presentation completed a feedback questionnaire. Eighteen were SHOs, 19 were SpRs in histopathology, and one was of unknown grade.

\section{Quantitative analysis}

Seventeen SHOs and 17 SpRs felt that the video presentations were of benefit to the course (strongly agree/agree), with 16 SHOs and 15 SpRs stating that the videos enhanced their learning experience. SHOs appeared to find the videos more beneficial than SpRs: 13 SHOs felt that it would have been difficult to learn as much about necropsies without viewing the videos, whereas 11 of the SpRs felt that this was the case. Moreover, SHOs were more likely (seven of $18 v$ one of 19) than SpRs to agree strongly that it would have been difficult to learn as much about necropsies without viewing the videos. Thirty four of the delegates strongly agreed/agreed that the videos were interesting and 35 enjoyed watching the videos. Tables 3-8 summarise the results.

\section{Qualitative analysis}

Twenty six themes were identified and grouped into six "metathemes", namely: (1) the usefulness of the videos; (2) unhelpful aspects of the videos; (3) comparing the videos with mortuary based teaching; (4) how the videos could be improved; (5) how to view the videos; and (6) recommending

Abbreviations: $\mathrm{SHO}$, senior house officer; SpR, specialist registrar 
Table 1 Contents of the necropsy video series used in our study

\begin{tabular}{|c|c|c|c|}
\hline & Video & Contents & $\begin{array}{l}\text { Running time } \\
\text { (minutes) }\end{array}$ \\
\hline 1 & $\begin{array}{l}\text { Health and safety, evisceration, } \\
\text { and reconstruction }\end{array}$ & $\begin{array}{l}\text { Health and safety } \\
\text { Safe sharps practice } \\
\text { Protective clothing/equipment } \\
\text { Mortuary suite design } \\
\text { Evisceration of body } \\
\text { Reconstruction }\end{array}$ & 24 \\
\hline 2 & Hospital necropsies & $\begin{array}{l}\text { External examination } \\
\text { Résumé of evisceration techniques } \\
\text { Dissection of internal organs } \\
\text { Demonstration of findings }\end{array}$ & 21 \\
\hline 3 & Axial techniques & $\begin{array}{l}\text { Dissection of strap muscles of neck } \\
\text { Removing the brain } \\
\text { Removing the eyes } \\
\text { Removing the temporal bones } \\
\text { Removing the spinal cord } \\
\text { Examination of the middle ears }\end{array}$ & 24 \\
\hline 4 & Specialist techniques & $\begin{array}{l}\text { Demonstration of pneumothorax } \\
\text { Demonstration of cardiac air embolus } \\
\text { Removing the femur } \\
\text { Examining the deep calf veins } \\
\text { Examining the rectus sheath } \\
\text { Dissection of intact female } \\
\text { genitourinary tract } \\
\text { Sampling for toxicology }\end{array}$ & 19 \\
\hline
\end{tabular}

videos to colleagues (33 delegates reported that they would recommend the videos to their colleagues). Table 9 presents the (meta) themes.

\section{DISCUSSION}

Currently, trainee histopathologists must demonstrate competence in necropsy practice in addition to surgical pathology. Such competence has traditionally been acquired via an apprenticeship in the mortuary (perhaps with little supervision) and reference to the relatively few available textbooks on necropsy practice. The continued decline in the hospital necropsy rate during the past 20 years ${ }^{12}{ }^{13}$ means that trainees may struggle to gain sufficient exposure to standard and specialist techniques, particularly if they are unable to perform medicolegal necropsies. ${ }^{8}$

There is an extensive literature on the uses of the necropsy in medical practice and undergraduate medical education. ${ }^{14}$ Given the increasing requirement that medical education be

\section{Table 2 Questionnaire prompts}

\begin{tabular}{ll}
\hline Question style & Questions \\
\hline Likert & The videos were of great benefit to this course \\
& The videos have enhanced my learning in this course \\
It would have been difficult to learn as much about the \\
necropsy without using the videos \\
The videos were well integrated in the teaching of this \\
course \\
The videos were very interesting \\
I enjoyed watching the videos \\
Content of the videos \\
What I found useful \\
response text \\
What I did not find useful \\
Do you think the videos can be seen as a series, on their \\
own, or in both ways? \\
What benefits do you see in using the necropsy videos \\
over traditional teaching methods? \\
Would you recommend the videos to your colleagues, \\
and if so, why? \\
In what ways can the videos be improved? \\
Have you any other comments?
\end{tabular}

grounded in educational theory and research, ${ }^{15}$ it is perhaps surprising that there are only occasional studies investigating postmortem techniques. ${ }^{16}$ No study has evaluated methods of postgraduate necropsy training. Previous studies have shown the usefulness of videos, video stills, ${ }^{17}$ video links, ${ }^{5}$ and computer assisted learning packages ${ }^{18-20}$ in the teaching of morbid anatomy ${ }^{21}$ and pathology to undergraduates. Ours is the first study to explore the use of videos as an adjunct to the mortuary based teaching of necropsy dissection techniques to histopathology trainees.

Using the survey as a research methodology, ${ }^{22}{ }^{23}$ with a questionnaire to collect a combination of quantitative and qualitative data, we have shown that structured, scripted videos may provide a useful adjunct to postgraduate training. Our study shows that such videos are acceptable to trainees, and enjoyable to watch. Furthermore, the trainees (and especially the SHOs) in our study subjectively felt that the videos enhanced their learning of necropsy techniques.

"The continued decline in the hospital necropsy rate during the past 20 years means that trainees may struggle to gain sufficient exposure to standard and specialist techniques"

Participants felt that videos demonstrating specialist techniques (techniques that all necropsy pathologists should be familiar with but which do not form part of every necropsy) were most relevant to their training. This probably reflects the declining hospital necropsy rate and concomitant decline in the opportunity to witness and perform such procedures. Moreover, it may reflect our intention when producing the videos that the demonstration of general necropsy procedures (video 2) would be mostly directed at the needs of undergraduates.

Producing the series of videos used in our study was both expensive and extremely time consuming, given the need for script writing, sound and film crews, editing, voice overs, and graphics. The four programmes were originally designed to be viewable both as a series and to stand alone. Judging from the qualitative data (metatheme 5), this objective was 
Table 3 Delegates' responses to the statement: the videos enhanced my learning experience on the course

\begin{tabular}{llllll}
\hline & $\begin{array}{l}\text { Strongly agree } \\
\mathbf{N}(\%)\end{array}$ & $\begin{array}{l}\text { Agree } \\
\mathbf{N}(\%)\end{array}$ & $\begin{array}{l}\text { Disagree } \\
\mathbf{N}(\%)\end{array}$ & $\begin{array}{l}\text { Strongly disagree } \\
\mathbf{N}(\%)\end{array}$ & $\begin{array}{l}\text { Total } \\
\mathbf{N}\end{array}$ \\
\hline Grade & $7(38.9)$ & $9(50.0)$ & $2(11.1)$ & $0(0)$ & 18 \\
SHO & $3(16.7)$ & $12(66.7)$ & $1(5.6)$ & $2(11.1)$ & 18 \\
SpR & $0(0)$ & $1(100)$ & $0(0)$ & $0(0)$ & 1 \\
Unknown & $10(27.0)$ & $22(59.5)$ & $3(8.1)$ & $2(5.4)$ & 37 \\
Total & & & \\
\hline \multicolumn{7}{l}{ SHO, senior house officer; SpR, specialist registrar. } \\
\hline
\end{tabular}

Table 4 Delegates' responses to the statement: it would have been difficult to learn as much about the necropsy without using the videos

\begin{tabular}{|c|c|c|c|c|c|}
\hline & $\begin{array}{l}\text { Strongly agree } \\
\mathbf{N}(\%)\end{array}$ & $\begin{array}{l}\text { Agree } \\
\mathrm{N}(\%)\end{array}$ & $\begin{array}{l}\text { Disagree } \\
\mathrm{N}(\%)\end{array}$ & $\begin{array}{l}\text { Strongly disagree } \\
\mathrm{N}(\%)\end{array}$ & $\begin{array}{l}\text { Total } \\
\mathrm{N}\end{array}$ \\
\hline \multicolumn{6}{|l|}{ Grade } \\
\hline $\mathrm{SHO}$ & $7(41.2)$ & $6(35.3)$ & $3(17.7)$ & $1(5.9)$ & 17 \\
\hline SpR & $1(5.3)$ & $10(52.6)$ & $7(36.8)$ & $1(5.3)$ & 19 \\
\hline Unknown & $0(0)$ & $0(0)$ & $1(100)$ & $0(0)$ & 1 \\
\hline Total & $8(21.6)$ & 16 (43.2) & $11(29.7)$ & $2(5.4)$ & 37 \\
\hline
\end{tabular}

Table 5 Delegates' responses to the statement: the videos were of great benefit to the course

\begin{tabular}{llllll}
\hline & $\begin{array}{l}\text { Strongly agree } \\
\text { N }(\%)\end{array}$ & $\begin{array}{c}\text { Agree } \\
\mathbf{N}(\%)\end{array}$ & $\begin{array}{l}\text { Disagree } \\
\mathbf{N}(\%)\end{array}$ & $\begin{array}{l}\text { Strongly disagree } \\
\mathbf{N}(\%)\end{array}$ & $\begin{array}{l}\text { Total } \\
\mathbf{N}\end{array}$ \\
\hline Grade & $9(50.0)$ & $8(44.4)$ & $1(5.6)$ & $0(0)$ & 18 \\
SHO & $6(31.6)$ & $11(57.9)$ & $1(5.3)$ & $1(5.3)$ & 19 \\
SpR & $0(0)$ & $1(100)$ & $0(0)$ & $0(0)$ & 1 \\
Unknown & $15(39.5)$ & $20(52.6)$ & $2(5.3)$ & $1(2.6)$ & 38 \\
Total & & & \\
\hline \multicolumn{7}{l}{ SHO, senior house officer; SpR, specialist registrar. } \\
\hline
\end{tabular}

Table 6 Delegates' responses to the statement: the videos were well integrated into the course

\begin{tabular}{|c|c|c|c|c|c|c|}
\hline & & $\begin{array}{l}\text { Strongly agree } \\
\mathrm{N}(\%)\end{array}$ & $\begin{array}{l}\text { Agree } \\
\mathrm{N}(\%)\end{array}$ & $\begin{array}{l}\text { Disagree } \\
\mathrm{N}(\%)\end{array}$ & $\begin{array}{l}\text { Strongly disagree } \\
\mathrm{N}(\%)\end{array}$ & $\begin{array}{l}\text { Total } \\
\mathrm{N}\end{array}$ \\
\hline Grade & $\begin{array}{l}\text { SHO } \\
\text { SpR }\end{array}$ & $\begin{array}{l}6(33.3) \\
3(15.8)\end{array}$ & $\begin{array}{l}11(61.1) \\
13(68.4)\end{array}$ & $\begin{array}{l}1(5.6) \\
1(5.3)\end{array}$ & $\begin{array}{l}0(0) \\
2(10.5)\end{array}$ & $\begin{array}{l}18 \\
19\end{array}$ \\
\hline Total & Unknown & $\begin{array}{l}0(0) \\
9(23.7)\end{array}$ & $\begin{array}{c}1(100) \\
25(65.8)\end{array}$ & $\begin{array}{l}0(0) \\
2(5.3)\end{array}$ & $\begin{array}{l}0(0) \\
2(5.3)\end{array}$ & $\begin{array}{r}1 \\
38\end{array}$ \\
\hline
\end{tabular}

$\mathrm{SHO}$, senior house officer; SpR, specialist registrar.

Table 7 Delegates' responses to the statement: the videos were very interesting

\begin{tabular}{llllll}
\hline & $\begin{array}{llll}\text { Strongly agree } \\
\mathbf{N}(\%)\end{array}$ & $\begin{array}{l}\text { Agree } \\
\mathbf{N}(\%)\end{array}$ & $\begin{array}{l}\text { Disagree } \\
\mathbf{N}(\%)\end{array}$ & $\begin{array}{l}\text { Strongly disagree } \\
\mathbf{N}(\%)\end{array}$ & $\begin{array}{l}\text { Total } \\
\mathbf{N}\end{array}$ \\
\hline Grade & $7(38.9)$ & $10(55.6)$ & $1(5.6)$ & $0(0)$ & 18 \\
SHO & $4(21.1)$ & $14(73.7)$ & $0(0)$ & $1(5.3)$ & 19 \\
SpR & $0(0)$ & $1(100)$ & $0(0)$ & $0(0)$ & 1 \\
Unknown & $11(29.0)$ & $25(65.8)$ & $1(2.6)$ & $1(2.6)$ & 38 \\
Total & & & \\
\hline \multicolumn{2}{l}{ SHO, senior house officer; SpR, specialist registrar. } \\
\hline
\end{tabular}


Table 8 Delegates' responses to the statement: I enjoyed watching the videos

\begin{tabular}{llllll}
\hline & Strongly agree & Agree & Disagree & Strongly disagree & Total \\
& $\mathbf{N}(\%)$ & $\mathbf{N}(\%)$ & $\mathbf{N}(\%)$ & $\mathbf{N}(\%)$ & $\mathbf{N}$ \\
\hline Grade & $5(27.8)$ & $13(72.2)$ & $0(0)$ & $0(0)$ & 18 \\
SHO & $3(15.8)$ & $14(73.7)$ & $1(5.3)$ & $1(5.3)$ & 19 \\
SpR & $0(0)$ & $1(100)$ & $0(0)$ & $0(0)$ & 1 \\
Unknown & $8(21.1)$ & $28(73.7)$ & $1(2.6)$ & $1(2.6)$ & 38 \\
Total & & & \\
\hline \multicolumn{7}{l}{ SHO, senior house officer; SpR, specialist registrar. } \\
\hline
\end{tabular}

Table 9 Thematic analysis of qualitative data

\begin{tabular}{|c|c|c|c|c|}
\hline Metatheme & Theme & & $\mathbf{N}$ & Description \\
\hline \multirow[t]{4}{*}{$\begin{array}{l}\text { (1) The usefulness } \\
\text { of the videos }\end{array}$} & a & $\begin{array}{l}\text { Teaching specialist } \\
\text { necropsy techniques }\end{array}$ & 17 & $\begin{array}{l}\text { Videos are useful in teaching specialist necropsy techniques (especially dissection of the spinal } \\
\text { cord, middle ear, and eyes; videos } 3 \text { and } 4 \text { )-for example, "seeing necropsy techniques that are } \\
\text { not performed often was particularly useful" }\end{array}$ \\
\hline & $b$ & $\begin{array}{l}\text { Teaching about } \\
\text { health and safety }\end{array}$ & 1 & The videos are useful in teaching about "health and safety" (video 1) \\
\hline & c & $\begin{array}{l}\text { Giving a broad } \\
\text { overview }\end{array}$ & 1 & $\begin{array}{l}\text { The videos have a role to play in providing "a broad overview of general necropsy techniques" } \\
\text { (video 2) }\end{array}$ \\
\hline & $d$ & Revision aid & 1 & The videos are a valuable tool for "reinforcement of previous knowledge and experience" \\
\hline \multirow[t]{5}{*}{$\begin{array}{l}\text { (2) Unhelpful } \\
\text { aspects of the } \\
\text { videos }\end{array}$} & $\mathrm{e}$ & Repetition & 8 & $\begin{array}{l}\text { Repetition of various procedures was considered unhelpful. These included the programme } \\
\text { introductions and evisceration of the brain. One respondent noted repeated viewing of the } \\
\text { programmes (for example "I have seen them several times now...") to be unhelpful }\end{array}$ \\
\hline & f & Lack of detail & 4 & $\begin{array}{l}\text { Insufficient attention was given to general necropsy dissection techniques (video 2)-for } \\
\text { example, "(dissection of) abdominal and thoracic organs possibly not quite detailed enough", } \\
\text { "more time needed on heart" }\end{array}$ \\
\hline & g & $\begin{array}{l}\text { No standard method } \\
\text { of dissection }\end{array}$ & 2 & $\begin{array}{l}\text { The techniques demonstrated differed from those described in the practical demonstration-for } \\
\text { example, "every technique was different from this morning as shown live. Good to experience } \\
\text { different ways but some conflict and disarray of thoughts" }\end{array}$ \\
\hline & h & Technical aspects & 1 & $\begin{array}{l}\text { Technical aspects of the video, such as the colour washing used during the introduction are } \\
\text { distracting - for example, "the starting } 2-3 \text { minutes is an unnerving yellow orange colour" }\end{array}$ \\
\hline & $\mathrm{i}$ & - & 1 & $\begin{array}{l}\text { One delegate reported that the demonstration of the technique for "obtaining CSF from the 4th } \\
\text { ventricle" was unhelpful, but did not state why }\end{array}$ \\
\hline \multirow{7}{*}{$\begin{array}{l}\text { (3) Comparing the } \\
\text { videos with mortuary } \\
\text { based teaching }\end{array}$} & k & $\begin{array}{l}\text { Specialist } \\
\text { procedures }\end{array}$ & 9 & $\begin{array}{l}\text { Videos excel over mortuary based teaching in the teaching of specialist necropsy techniques- } \\
\text { for example, "can demonstrate methods which are not part of a 'normal' necropsy" }\end{array}$ \\
\hline & I & Revision & 7 & $\begin{array}{l}\text { Videos are a valuable tool for revising and reinforcing techniques learnt in the mortuary-for } \\
\text { example, "can be used to reinforce traditional teaching methods" }\end{array}$ \\
\hline & $\mathrm{m}$ & Clear and concise & 6 & $\begin{array}{l}\text { Videos are clearer and more concise than other learning media-for example, "clear, straight } \\
\text { forward explanations with good examples" }\end{array}$ \\
\hline & $\mathrm{n}$ & $\begin{array}{l}\text { Studying at one's } \\
\text { own pace }\end{array}$ & 5 & $\begin{array}{l}\text { Videos are valued over mortuary based teaching because they allow one to study at one's own } \\
\text { speed-for example, "always available, can be studied alone" and "can rewind and watch } \\
\text { again" }\end{array}$ \\
\hline & $\circ$ & $\begin{array}{l}\text { Large group } \\
\text { teaching }\end{array}$ & 3 & $\begin{array}{l}\text { Videos are more amenable to large group teaching-for example, "enables large groups to } \\
\text { gain teaching experience" }\end{array}$ \\
\hline & $\mathrm{p}$ & Hands on teaching & 7 & $\begin{array}{l}\text { Seven delegates noted that mortuary based teaching was superior to videos although most did } \\
\text { not state why-for example, "seeing/doing the real thing teaches best", "always better to see } \\
\text { PMs live". One delegate offered insight into this theme, observing that "hands on teaching can } \\
\text { be easier to learn from" }\end{array}$ \\
\hline & $q$ & Interactivity & 1 & $\begin{array}{l}\text { Videos lack interactivity because one "cannot interrupt to clarify doubts as opposed to a live } \\
\text { demonstration" }\end{array}$ \\
\hline \multirow[t]{3}{*}{$\begin{array}{l}\text { (4) How the videos } \\
\text { could be improved }\end{array}$} & $r$ & $\begin{array}{l}\text { Include more } \\
\text { specialist techniques }\end{array}$ & 5 & $\begin{array}{l}\text { The videos could have been more comprehensive and included "further rarely performed } \\
\text { technique, demonstrations - for example, mesenteric vessels in ischaemic bowel, post-op hearts, } \\
\text { forensic cases", "...(dissection of) internal carotid arteries, vertebral arteries...", and "more on } \\
\text { middle/inner ear (dissection)" }\end{array}$ \\
\hline & s & $\begin{array}{l}\text { Give more detailed } \\
\text { explanations }\end{array}$ & 5 & $\begin{array}{l}\text { The videos would benefit from the inclusion of a more detailed explanation of some aspects of } \\
\text { the necropsy-for example, "...step by step evisceration..." and making the dissection "slower } \\
\text { to demonstrate unusual parts of the dissection" }\end{array}$ \\
\hline & $t$ & Reduce repetition & 4 & The videos could be improved by "by reducing repeated elements" \\
\hline \multirow{3}{*}{$\begin{array}{l}\text { (5) How to use the } \\
\text { videos }\end{array}$} & u & Versatile & 24 & The videos could equally be viewed individually or as a series \\
\hline & $v$ & View as a series & 6 & $\begin{array}{l}\text { The videos were best viewed as a series, "maybe in association with relevant section(s) of (the) } \\
\text { course" }\end{array}$ \\
\hline & w & View individually & 4 & $\begin{array}{l}\text { The videos would be best viewed individually, because "as a series there was some repetition of } \\
\text { CNS evisceration" }\end{array}$ \\
\hline \multirow[t]{4}{*}{$\begin{array}{l}\text { (6) Recommending } \\
\text { videos to colleagues }\end{array}$} & $\mathrm{x}$ & $\begin{array}{l}\text { Informative and } \\
\text { instructive }\end{array}$ & 13 & $\begin{array}{l}\text { The videos were regarded as informative and instructive, especially for specialist techniques - for } \\
\text { example, "specialist techniques are rarely taught", and "very informative didactic approach" }\end{array}$ \\
\hline & y & $\begin{array}{l}\text { Valuable } \\
\text { departmental } \\
\text { resource }\end{array}$ & 4 & $\begin{array}{l}\text { The video series would be a valuable departmental resource-for example, "(would } \\
\text { recommend) as a reference within a department", "they provide excellent clear demonstration } \\
\text { which would be handy to have at our side" }\end{array}$ \\
\hline & z & $\begin{array}{l}\text { Of great practical } \\
\text { value }\end{array}$ & 4 & $\begin{array}{l}\text { Recommended using the videos as a practical aide to necropsy teaching because they were } \\
\text { "very clear" and "of great practical value" }\end{array}$ \\
\hline & $\alpha$ & Basic training & 3 & $\begin{array}{l}\text { Would recommend that junior colleagues saw the videos "as a basic foundation" to learning } \\
\text { necropsy techniques }\end{array}$ \\
\hline
\end{tabular}




\section{Take home messages}

- Educational videos of necropsy techniques are expensive and time consuming to produce, and require the consent of the relatives of the deceased

- Videos can be an acceptable, enjoyable, and informative adjunct to mortuary based teaching

- Videos may be used to teach trainees about specialist dissection techniques rarely encountered in the mortuary

- Videos are especially useful for juniors at the start of their training

achieved. However, as a consequence, there was a necessary degree of repetition, which participants found distracting when viewing the programmes together (theme w). In aiming to give undergraduates an idea of what the necropsy entails, the demonstration of general necropsy techniques and eviscerations was regarded by some trainees as being too cursory to be helpful (theme f). Some technical aspects of the videos were not to the tastes of all delegates-such as the use of a colour wash over the images during the introductions to the programmes (theme $\mathrm{h}$ ). Such issues should be borne in mind when designing future videos for necropsy teaching (metatheme 4).

Videos can be made accessible to large numbers of students at one time (via a data projector), and students may watch them on their own (or in small groups) in their own time and at their own pace (themes $\mathrm{n}$ and $\mathrm{o}$ ). Videos can also deliver focused teaching on specific aspects of necropsy technique (themes $\mathrm{k}$ and $\mathrm{m}$ ).

We conclude that videos can form a valuable and acceptable adjunct to mortuary based teaching when training histopathology trainees in necropsy techniques. Such videos appear most useful when demonstrating specialist techniques rarely encountered at necropsy to junior trainees, but continue to have a role for more experienced trainees revising for examinations.

\section{ACKNOWLEDGEMENTS}

We would like to thank the staff at the University of Sheffield learning media unit, and especially Ms C Allam who assisted us in the production of the videos used in this study.

\section{Authors' affiliations}

Dr J L Burton, Academic Unit of Pathology, University of Sheffield Medical School, Beech Hill Road, Sheffield S10 2RX, UK

Ms G Diercks-O'Brien, Learning Media Unit, University of Sheffield, 5 Favell Road, Sheffield S3 7QX, UK

Prof. G N Rutty, Division of Forensic Pathology, Robert Kilpatrick

Building, Leicester Royal Infirmary, PO Box 65, Leicester LE2 7LX, UK

\section{REFERENCES}

1 DeRoy AK. The autopsy as a teaching-learning tool for medical undergraduates. J Med Educ 1976;51:1016-18.

2 Hartmann WH. Contributions of the autopsy to medical education. J Clin Pathol 1978;69:228-9.

3 Smith JC. Utilizing the autopsy for medical education. J Med Educ 1978;53:435-6.

4 Berthrong $M$. The autopsy as a vehicle for the lifetime education of pathologists. Arch Pathol Lab Med 1984;108:506-9.

5 Goudie RB, Harris P, Patterson W. How do we teach pathology? Post-mortems by video. J Pathol 1988;154:195-7.

6 Benbow EW. Why show autopsies to medical students. J Pathol 1990:162:187-8.

7 Hill RB, Anderson RE. The uses and value of autopsy in medical education as seen by pathology educators. Acad Med 1991;66:97-100.

8 Burton JL, Wells M. The Alder Hey affair: implications for pathology practice. J Clin Pathol 2001;54:820-3.

9 Burton JL, Rutty GN. The autopsy. 2000. Sheffield: The University of Sheffield Learning Media Unit.

10 Burton JL, McDonald S. Curriculum or syllabus: which are we reforming? Med Teach 2001;23:187-91.

11 Pope C, Zeibland S, Mays V. Qualitative research in health care: analysing qualitative data. BMJ 2000;320:114-16.

12 Underwood JCE. Autopsies and clinical audit. In: Burton JL, Rutty GN, eds. The hospital autopsy. London: Arnold, 2001:170-7.

13 Start RD, McCulloch TA, Benbow EW, et al. Clinical autopsy rates during the 1980s: the continued decline. J Pathol 1993;171:63-6.

14 Burton JL. The autopsy in modern undergraduate medical education: a qualitative study of uses and curriculum considerations. Med Educ 2003;37:1073-81.

15 General Medical Council. Tomorrow's doctors: Recommendations on undergraduate medical education. 2002. London: General Medical Council.

16 Walker JEC, Rutty GN, Rodgers B, et al. How should the chest wall be opened at necropsy? J Clin Pathol 2002;55:72-5.

17 Hunt NCA, James DS, Bull AD. The still video camera: a suitable and convenient method of demonstrating post mortem findings. Med Educ 1997;31:386-9.

18 Quentin-Baxter M Dewhurst D. An interactive computer-based alternative to performing a rat dissection in the classroom. J Biol Educ 1992;26:27-33.

19 Guy JF, Frisby AJ. Using interactive videodiscs to teach gross anatomy to undergraduates at the Ohio State University. Acad Med 1992;67:132-3.

20 Gunn C, Maxwell L. CAL in human anatomy. Journal of Computer Assisted Learning 1996;12:205-15.

21 Zirkel JB, Zirkel PA. Technological alternatives to actual dissection in anatomy instruction: a review of the research. Educational Technology 1997;37:52-6.

22 Taylor SJ, Bogdon R. Introduction: Go to the people. In: Introduction to qualitative research methods: a guidebook and resource. Chichester: John Wiley and Sons Inc, 1998:3-5

23 Sparkes AC. The paradigms debate: an extended review and a celebration of difference. In: Sparkes AC, ed. Research in physical education and sport: exploring alternative visions. London: Falmer Press, 1992:9-60. 